\title{
Preweaned heifer management on US dairy operations: Part II. Factors associated with colostrum quality and passive transfer status of dairy heifer calves
}

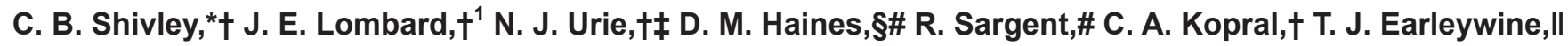 \\ J. D. Olson,ף and F. B. Garry† \\ *Department of Animal Sciences, College of Agricultural Sciences, Colorado State University, Fort Collins 80523-1171 \\ †USDA-Animal and Plant Health Inspection Service (APHIS)-Veterinary Services (VS) Center for Epidemiology and Animal Health, \\ National Animal Health Monitoring System, Fort Collins, CO 80526-8117 \\ ‡Department of Clinical Sciences, College of Veterinary Medicine and Biomedical Sciences, Colorado State University, Fort Collins 80523-1678 \\ $\S$ Department of Veterinary Microbiology, Western College of Veterinary Medicine, University of Saskatchewan, Saskatoon, Saskatchewan, \\ Canada S7N 5B4 \\ \#The Saskatoon Colostrum Company Ltd., Saskatoon, Saskatchewan, Canada S7K 6A2 \\ IILand O'Lakes Animal Milk Products Co., Cottage Grove, WI 53527 \\ IZZetis, 5 Giralda Farms, Madison, NJ 07940
}

\section{ABSTRACT}

Passive transfer of immunity is essential for the shortand long-term health of dairy calves. The objective of this study was to evaluate factors associated with colostrum quality and passive transfer status of US heifer calves. This study included 104 operations in 13 states that participated in the calf component of the National Animal Health Monitoring System's Dairy 2014 study. This 18-mo longitudinal study included 1,972 Holstein heifer calves from birth to weaning. Multivariable mixed linear regression models were selected using backward elimination model selection after univariate screening to determine which factors were associated with colostrum IgG and serum IgG concentrations. The mean colostrum IgG concentration was $74.4 \mathrm{~g} / \mathrm{L}$ with $77.4 \%$ of colostrum samples having IgG concentrations $>50 \mathrm{~g} / \mathrm{L}$. The final model for colostrum IgG included colostrum source and a categorized temperature-humidity index value (cTHI) for the month before calving. Mean colostrum IgG concentrations were highest for dams in third and higher lactations $(84.7 \mathrm{~g} / \mathrm{L})$ and lowest for commercial colostrum replacers $(40.3 \mathrm{~g} / \mathrm{L})$. Colostrum IgG concentrations were highest for cTHI $\geq 70(72.6 \mathrm{~g} / \mathrm{L})$ and lowest for cTHI $<40(64.2 \mathrm{~g} / \mathrm{L})$. The mean serum IgG concentration was $21.6 \mathrm{~g} / \mathrm{L}$, with $73.3 \%$ of calves having serum IgG concentrations $>15 \mathrm{~g} / \mathrm{L}$. The final model for serum IgG concentration included region, heat treatment of colostrum, colostrum source, timing to first feeding, volume of colostrum fed in the first

Received October 17, 2017.

Accepted May 5, 2018.

${ }^{1}$ Corresponding author: Jason.E.Lombard@aphis.usda.gov
$24 \mathrm{~h}$, age of the calf at blood sampling, and colostrum IgG concentration. Mean serum IgG concentrations were highest for calves that received colostrum from first-lactation dams $(25.7 \mathrm{~g} / \mathrm{L})$ and lowest for calves fed commercial colostrum replacer $(16.6 \mathrm{~g} / \mathrm{L})$. Serum $\mathrm{IgG}$ concentrations were higher for calves fed heat-treated colostrum $(24.4 \mathrm{~g} / \mathrm{L})$ than for calves fed untreated colostrum (20.5 g/L). Serum IgG concentration was positively associated with the volume of colostrum fed in the first $24 \mathrm{~h}$ and colostrum IgG concentration, and negatively associated with the number of hours from birth to colostrum feeding and age (days) at blood collection. Dairy producers should be encouraged to measure the quality of colostrum before administering it to calves and to measure serum IgG or a proxy such as serum total protein or Brix to evaluate passive immunity and colostrum management programs.

Key words: colostrum quality, passive transfer status, dairy heifer calves

\section{INTRODUCTION}

Passive transfer of immunity via colostrum is essential for the short- and long-term health of dairy calves. Researchers have understood the importance of colostrum for prevention of disease in neonatal ruminants for over $100 \mathrm{yr}$ (Famulener, 1912), yet 19.2\% of calves in the United States still had failure of passive transfer (FPT) in 2007, with a serum IgG $<10 \mathrm{~g} / \mathrm{L}$ (Beam et al., 2009). Consumption and absorption of maternal immunoglobulins via colostrum are critical for reducing disease and mortality in calves in the first weeks of life, because calves are essentially agammaglobulinemic at birth (Gulliksen et al., 2008). The primary components of colostrum that contribute to passive immunity are 
immunoglobulins, which include $\operatorname{IgG}, \operatorname{IgA}$, and IgM; IgG comprises about $85 \%$ of the immunoglobulin in colostrum (Larson et al., 1980). Relative to IgG content, high-quality colostrum is defined as having an IgG concentration >50 g/L (McGuirk and Collins, 2004). In addition to water, colostrum contains important nutrients, such as protein, vitamins, minerals, and fat, which provides neonatal calves with supplemental heat energy. Factors previously associated with colostrum quality include parity (Zarcula et al., 2010), breed (Zarcula et al., 2010), and season of calving (Gulliksen et al., 2008; Ontsouka et al., 2003). Colostrum quality, which varies significantly among cows, affects passive transfer and warrants an updated evaluation.

In addition to the quality of colostrum fed, 3 important factors related to managing colostrum for adequate passive transfer should be considered: the quantity of colostrum fed, the timing of feeding, and the cleanliness of the colostrum (McGuirk and Collins, 2004). In regards to the amount of colostrum fed, the general recommendation is to feed at least $10 \%$ of $\mathrm{BW}$ of colostrum at the first feeding - about $4 \mathrm{~L}$ for the average size calf (Godden, 2008). Regarding the timing of the first colostrum feeding, calves should be fed their first colostrum as soon as possible, because the rate of immunoglobulin absorption decreases rapidly after $4 \mathrm{~h}$ following birth (Stott et al., 1979). Calves are only able to absorb large molecules, including immunoglobulins, during a brief period of 12 to $24 \mathrm{~h}$ following birth (Michanek et al., 1989). The cleanliness of the colostrum fed is crucial, as colostrum contaminated with bacteria can lead to decreased absorption of immunoglobulins due to competition at the intestinal epithelium (Stewart et al., 2005; Johnson et al., 2007).

A colostrum management program can be evaluated by measuring serum IgG or total protein concentrations in calves within the first week of life. If calves have a serum IgG concentration $<10 \mathrm{~g} / \mathrm{L}$ between 24 and $48 \mathrm{~h}$ following birth, they are considered to have FPT (Gay, 1983). Although $10 \mathrm{~g} / \mathrm{L}$ is considered the cutoff value for FPT, studies have shown that calves with serum IgG concentrations $>15 \mathrm{~g} / \mathrm{L}$ are better able to resist respiratory infections (Furman-Fratczak et al., 2011). Other studies have recommended using $20 \mathrm{~g} / \mathrm{L}$ as the cutoff value (Chigerwe et al., 2015). Failure of passive transfer increases calf morbidity and mortality and decreases calf growth (Nocek et al., 1984; Robison et al., 1988; Wells et al., 1996; Furman-Fratczak et al., 2011). Failure of passive transfer can also decrease productivity, including decreased rate of gain, decreased firstand second-lactation milk production, and increased culling rate during the first lactation (DeNise et al., 1989; Faber et al., 2005). Because of the serious conse- quences associated with FPT, colostrum management has been and should continue to be a focus of producer education programs (BAMN, 2001).

We believe this study will provide additional evidence to support current best practices for colostrum management, such as quality of colostrum and timing and amount of colostrum administration but will also identify other factors and practices that may lead to improved passive transfer status in dairy heifer calves. The objective of this study was to determine management practices and environmental factors associated with colostrum quality and passive transfer status of Holstein dairy heifer calves.

\section{MATERIALS AND METHODS}

\section{Study Design}

The USDA's National Animal Health Monitoring System (NAHMS) conducts national surveys to collect information on the health, management, and productivity of domestic livestock species (USDA, 2016). In 2014, a nationwide survey was conducted to collect information about the US dairy industry, including an 18-mo longitudinal dairy heifer calf study. All participation in NAHMS studies is voluntary. However, to participate in the longitudinal calf study, operations had to have completed both NAHMS Dairy 2014 surveys, and agreed to provide information on enrolled calves, whether raised onsite or offsite.

The calf component was part of the NAHMS Dairy 2014 study, and consisted of a convenience sample of 104 dairy operations, including both conventional and organic operations. These operations were located in 13 states, including California, Colorado, and Washington in the western region, and Iowa, Michigan, Minnesota, Missouri, New York, Ohio, Pennsylvania, Vermont, Virginia, and Wisconsin in the eastern region. Dairy operations were categorized based on the number of mature cows, as small (30 to 99 cows), medium-sized (100 to 499 cows), and large (500 or more cows).

Data collection for the calf component of the study occurred from March 2014 to September 2015. Data collectors were trained on data and sample collection. Each operation was initially instructed to enroll 24 heifer calves over a 1-yr period, or an average of 2 calves per month. Farm personnel selected which calves to enroll in the study. However, a calf must have been alive at $24 \mathrm{~h}$ of age to be enrolled. Because fewer operations participated than originally planned, the number of calves that could be enrolled per operation was increased to a range of 48 to 60 . Additionally, because enrollment of farms did not occur as quickly as had 
been anticipated, the study encompassed 18 mo instead of the 12-mo period that was originally planned.

\section{Heifer Calf Health Card}

Each calf enrolled in the study had a Heifer Calf Health Card ("Calf Card") to record information on events that occurred from birth to weaning (see https://www.aphis.usda.gov/animal_health/nahms/ dairy/downloads/dairy14ques/CalfHealth.pdf). The Calf Card included questions in English and Spanish and was filled out by farm personnel, a veterinary medical officer, extension personnel, veterinarians, or a combination of the people involved with calf raising. Sections of the Calf Card included birth data (such as birth date, weight, and calving ease), colostrum feeding data (including timing, volume, and method of colostrum feeding), preweaning housing and procedure data (such as housing, ventilation, bedding, and dehorning), milk feeding (including type of liquid diet fed, any additives, and method of feeding), milk consumption record (volume and frequency of feedings), preweaning growth record (hip height and heart girth recordings every $2 \mathrm{wk}$ ), biologic sampling record (including serum collection date), vaccinations, disease incidence and treatment, weaning data (weaning date, primary weaning criteria), and any additional notes. Additional information requested included starter feed labels and milk replacer labels (if applicable).

\section{Biological Sampling and Testing}

Before enrollment in the study, calves were screened for persistent infection with bovine viral diarrhea virus (BVDV). V-Cut ear notchers (Nasco, Fort Atkinson, WI) were used to collect ear notch samples from all calves, which were tested on-farm for BVDV using the Idexx SNAP BVDV Antigen Test (Idexx, Westbrook, $\mathrm{ME}$ ). Calves that tested positive for BVDV were excluded from the study. Colostrum samples $(40-50 \mathrm{~mL})$ from the first feeding of colostrum administered to the calf were collected in conical screw-top tubes by farm personnel and frozen until shipping. Blood samples (5 $\mathrm{mL}$ ) from calves between 1 and $7 \mathrm{~d}$ of age were collected in serum separator tubes by veterinary medical officers or animal health technicians, and samples were centrifuged if possible before shipping. Colostrum and serum samples were shipped together on ice to USDA's National Veterinary Services Laboratories (Ames, IA). Samples were then accumulated and shipped in batches to the Saskatoon Colostrum Company (Saskatoon, SK, Canada). Colostrum and serum samples were tested for IgG concentration using radial immunodiffusion. Re- sults from blood samples collected within $24 \mathrm{~h}$ of birth or after $7 \mathrm{~d}$ of age were excluded from this analysis.

Radial immunodiffusion was used to measure the concentration IgG in colostrum and serum. Each 24-mL agarose plate, prepared in house using commercially available ingredients and reagents, was punched with 42 wells (volume of $6 \mu \mathrm{L}$ each). Wells $1-4$ and 39-42 were for 2 replicates of each of the 4 calibrators used to generate the standard curve; wells $5-9$ and 10-14 were for each of the 2 reference standards that were used to qualify the plate; and wells $15-38$ were used for test samples. Serial 2-fold dilutions (1:4, 1:8, 1:16, 1:32) of the bovine IgG standard (Bovine Serum Calibrator Cat. no. 4005, Midland BioProducts Corp., Boone, IA), reference bovine serum [Center for Veterinary Biologics (Ames, IA) bovine IgG species standard working stock is further diluted 1:4], and reference colostrum (diluted 1:15) were prepared in PBS. A 1:4 dilution of test serum and a 1:15 dilution of test colostrum were prepared using PBS. Two replicates of $4 \mu \mathrm{L}$ of each dilution of the bovine IgG standard were dispensed for the standard curve. Two replicates of $4 \mu \mathrm{L}$ of the diluted reference colostrum and reference serum and $4 \mu \mathrm{L}$ of the diluted test sample were dispensed on the plate. The plates were incubated at 20 to $25^{\circ} \mathrm{C}$ for 18 to $19 \mathrm{~h}$ in a humidified chamber. As a measure of preservation to prevent microbial growth, sodium azide was added to the liquefied agarose solution to a final concentration of $0.01 \%$. A plate reader was used to measure and record the ring diameters for the precipitin rings surrounding the wells (digital RID reader AD400, The Binding Site Inc., San Diego, CA). Using the results (ring diameters) obtained for each of the 2-fold dilutions of the bovine $\operatorname{IgG}$ standard and a spreadsheet (Excel, Microsoft Corp., Redmond, WA) with calculation formulas, a regression line was generated for each plate for the variable $R$ (ring diameter) versus $\log _{10}$ (concentration). Individual plates were considered acceptable if the coefficient of determination was greater than 0.97 for the standard curve, and the mean values for the reference colostrum and reference serum were the expected values $\pm 10 \%$. Immunoglobulin concentration for the test sample was determined using the regression line of the bovine IgG standard obtained for each plate. The diameters were entered into a template where the regression line and immunoglobulin concentration $(\mathrm{g} / \mathrm{L})$ was calculated.

\section{Environmental Factors}

Monthly temperature-humidity index (THI) data by state and county were obtained from the National Oceanic and Atmospheric Administration (NOAA, 2016). The THI accounts for the effects of temperature and 
relative humidity, and the equation uses the dry bulb temperature $\left(\mathrm{T},{ }^{\circ} \mathrm{F}\right)$ and the relative humidity $(\mathrm{RH})$. The equation used for this analysis was THI $=\mathrm{T}-$ $[0.55-(0.55 \times \mathrm{RH} / 100)] \times(\mathrm{T}-58)$. County-level THI values were calculated and assigned to each calf for the month before birth for colostrum quality analysis and for passive transfer analysis. Temperature-humidity index values were then categorized according to the thermal neutral zone for a mature cow (cTHI) as follows for the month before birth for the analyses: cold stress (THI $<40$ ), thermoneutral (THI $\geq 40$ and $<70$ ), and heat stress (THI $\geq 70$ ). Because cold stress and heat stress likely influence colostrum production and passive transfer status, categories were created to account for the influence of low and high cTHI values compared with thermoneutral cTHI as a continuous variable.

Day-length data were obtained from the United States Naval Observatory for each state and averaged by month as hours and minutes of light per day (USNO, 2016). Each calf was assigned a day-length value for the month before birth for colostrum quality analysis, and the month of birth for passive transfer analysis.

\section{Statistical Analysis}

When each calf was weaned, the Calf Card was mailed to USDA NAHMS (Fort Collins, CO). Initial validation was performed on every Calf Card before data entry to check the accuracy of dates and other information. Data were then entered into SAS software (version 9.4; SAS Institute Inc., Cary, NC). After all Calf Cards were entered, the data were validated again by the NAHMS staff and merged with the results from the colostrum and serum testing obtained from the laboratory. Descriptive data were analyzed using the FREQUENCY and MEANS procedures for categorical and continuous variables, respectively.

Models were constructed to determine factors significantly associated with concentrations of IgG in colostrum and serum, with operation as the random variable. Predictor variables were considered for the models based on biological plausibility. For this analysis, only Holstein heifer calves with data for all of the variables initially included in the models were included in the analysis. For both colostrum and serum IgG model building, univariate linear regression models were used for screening. Variables with $P<0.20$ in the univariate screening were considered for inclusion in the multivariable mixed linear regression model. Stepwise backward elimination model selection in PROC MIXED was used to construct the final models, with variables with $P$ $<0.05$ considered significant and thus included in the model. All first-order interactions of the final model variables were evaluated for significance. Model fit was evaluated using the Akaike information criteria.

\section{RESULTS}

\section{Colostrum Quality}

Data analysis for colostrum quality included 1,972 of the 2,273 Holstein heifer calves included in the overall study (Figure 1). Only Holstein heifer calves were included in the analysis due to known breed differences in colostrum quality and the small sample size obtained for other breeds. The mean colostrum IgG concentration was $74.4 \mathrm{~g} / \mathrm{L}$ (SE 0.72), with $77.4 \%$ of samples having colostrum IgG concentrations $>50 \mathrm{~g} / \mathrm{L}$ (Table $1)$.

Initial variables included in the univariate screening for colostrum quality as indicated by colostrum IgG concentration included region, herd size, average day length for the month before calving for the state of the operation, categorized average cTHI value for the month before calving for the county of the operation, heat treatment of colostrum, and source of colostrum (Tables 1 and 2).

After univariate screening and stepwise backward elimination model selection, the variables included in the final model for colostrum $\operatorname{IgG}$ concentration were source of colostrum $(P<0.001)$ and a categorized average cTHI for the month before calving $(P=0.002$; Table 3). Colostrum IgG was highest for dams in third or higher lactations $(84.7 \mathrm{~g} / \mathrm{L}, \mathrm{SE} 2.26)$. Colostrum IgG concentrations from unknown-lactation dams and first- and second-lactation dams were not significantly different. Commercial colostrum replacers had the lowest colostrum IgG concentration (40.3 g/L, SE 6.72; Figure 2). Colostrum IgG concentrations were greater when cTHI values of the month before calving were categorized as $\geq 70$ than when the cTHI values were categorized as $<40[72.6 \mathrm{~g} / \mathrm{L}$ (SE 2.89) and $64.2 \mathrm{~g} / \mathrm{L}$ (SE 2.34), respectively].

\section{Passive Transfer of Immunity}

Data analysis for passive transfer of immunity included 1,623 Holstein heifer calves (Figure 1). The mean serum IgG was $21.6 \mathrm{~g} / \mathrm{L}$ (SE 0.25), with $73.3 \%$ of calves having serum IgG concentrations $\geq 15 \mathrm{~g} / \mathrm{L}$ (Table 4). Poor serum IgG concentrations $(<10 \mathrm{~g} / \mathrm{L})$ were reported in $12.1 \%$ of calves.

Initial variables included in the multivariable model after univariate screening for passive transfer status as indicated by serum IgG concentrations included region, a categorized average cTHI value for the month be- 


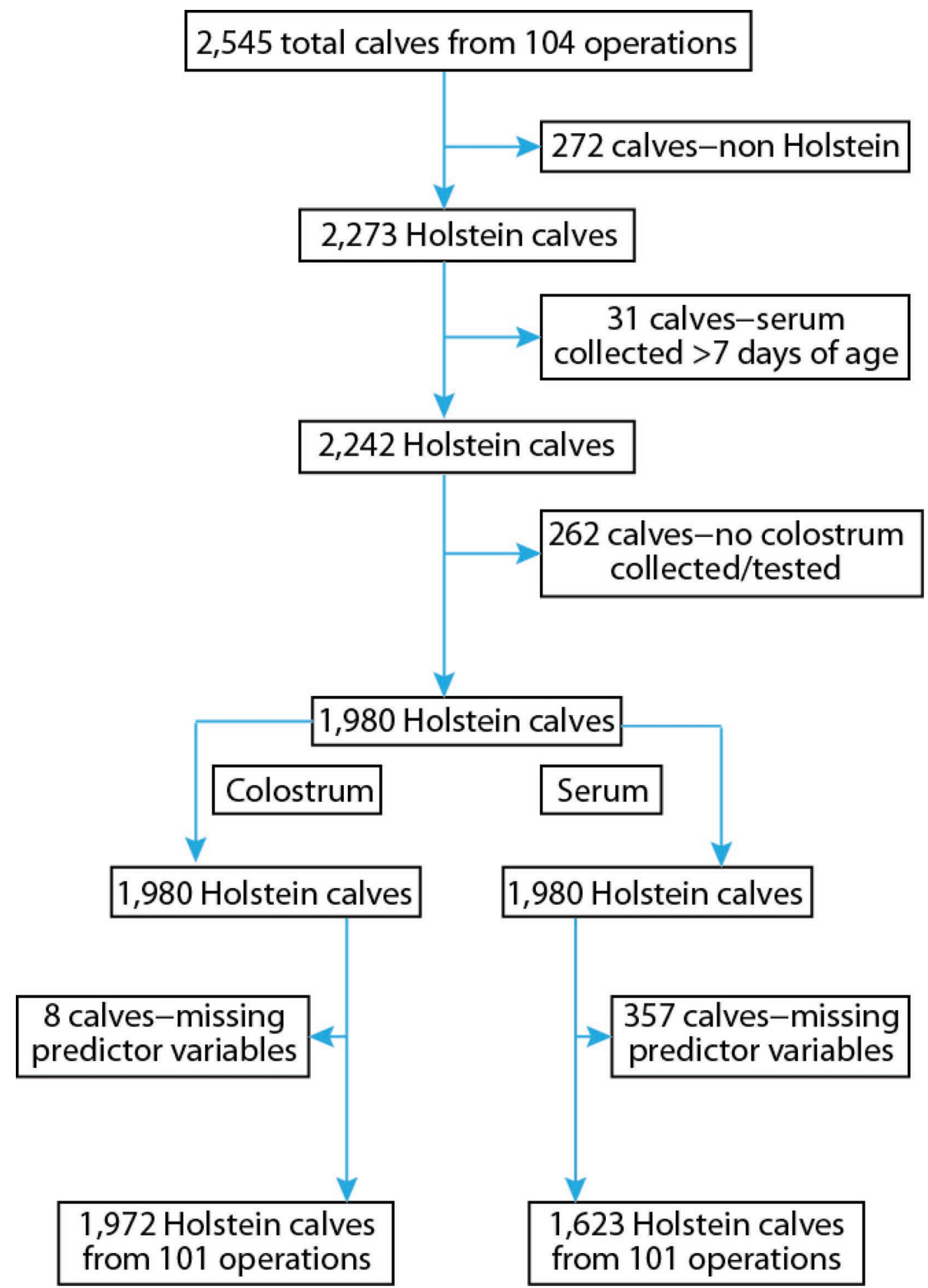

Figure 1. Flowchart of calf selection for colostrum IgG and serum IgG modeling from the overall NAHMS Dairy 2014 Study-Calf Component (USDA, 2016). Color version available online.

fore birth for the county, heat treatment of colostrum, source of colostrum, timing to first feeding of colostrum, total volume of colostrum fed in the first $24 \mathrm{~h}$ of life, age at blood sampling, dam lactation, number of calves, birth weight, and colostrum IgG concentration (Tables 4 and 5). 
Table 1. Percent of Holstein heifer calves for all categorical variables initially included in colostrum IgG univariate screening, by colostrum IgG category $^{1}$

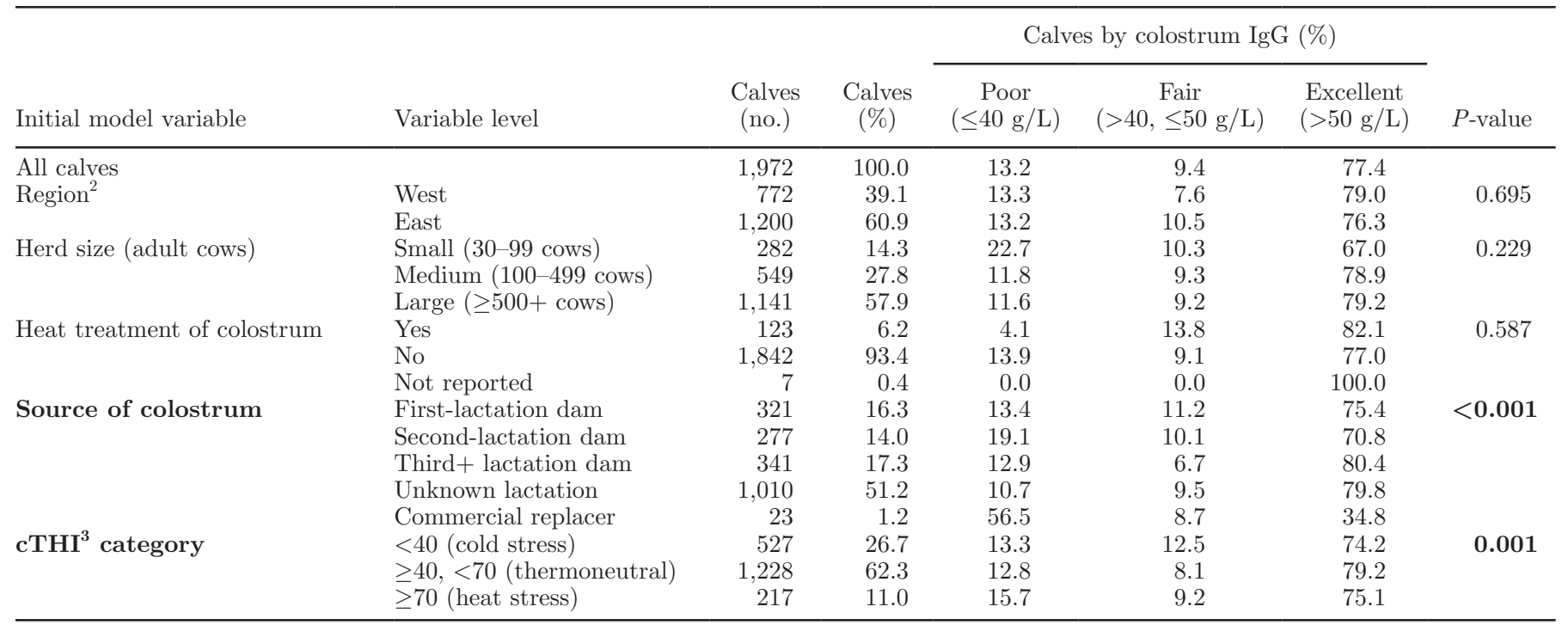

${ }^{1}$ Bolded variables were included in the initial multivariable colostrum IgG model $(P$-value $<0.20)$.

${ }^{2}$ West region $=$ California, Colorado, Washington; East region = Iowa, Michigan, Minnesota, Missouri, New York, Ohio, Pennsylvania, Vermont, Virginia, and Wisconsin.

${ }^{3}$ Temperature-humidity index according to the thermal neutral zone for a mature cow for the month before calving.

The final multivariable model for serum IgG concentrations in calves included region $(P=0.041)$, heat treatment of colostrum $(P=0.018)$, source of colostrum $(P<0.001)$, timing to the first feeding $(P=$ $0.004)$, total volume of colostrum fed in the first $24 \mathrm{~h}$ $(P=0.013)$, age of the calf at blood sampling $(P<$ $0.001)$, and colostrum IgG concentration $(P<0.001)$ (Table 6). Serum IgG was higher for calves raised in the western region $(23.5 \mathrm{~g} / \mathrm{L}, \mathrm{SE} 1.25)$ than for calves raised in the eastern region $(21.5 \mathrm{~g} / \mathrm{L}, \mathrm{SE} 0.92)$. Serum IgG was higher for calves fed heat-treated colostrum (24.4 g/L, SE 1.72) compared with calves fed colostrum that was not heat treated $(20.5 \mathrm{~g} / \mathrm{L}, \mathrm{SE} 0.61)$. Serum IgG was the highest in calves that received colostrum from first-lactation dams $(25.7 \mathrm{~g} / \mathrm{L}, \mathrm{SE} 1.11)$ and lowest for calves fed commercial colostrum replacer (16.6 $\mathrm{g} / \mathrm{L}, \mathrm{SE}$ 2.21) (Figure 3). For each 1-h delay following birth to colostrum feeding, serum IgG decreased 0.32 $\mathrm{g} / \mathrm{L}$ (SE 0.11). Within the range of observed colostrum IgG values, for each 1-L increase of colostrum fed in the first $24 \mathrm{~h}$ after birth, serum IgG increased $0.57 \mathrm{~g} / \mathrm{L}$ (SE 0.21). For each day following birth to collection of the blood, serum IgG decreased $0.71 \mathrm{~g} / \mathrm{L}$ (SE 0.16). For every $10 \mathrm{~g} / \mathrm{L}$ increase in colostrum IgG concentration, the serum IgG increased $1.1 \mathrm{~g} / \mathrm{L}$ (SE 0.10).

\section{Failure of Passive Transfer}

Calves with FPT were described by risk factors commonly associated with FPT. Among the 1,623 calves included in the passive transfer analysis, $12.1 \%$ of calves were considered to have had FPT of immunity (serum IgG below $10 \mathrm{~g} / \mathrm{L}$ ). Risk factors commonly associated with FPT included poor colostrum quality (colostrum IgG concentration $\leq 50 \mathrm{~g} / \mathrm{L}$ ), delayed feeding of colostrum (first feeding $\geq 4 \mathrm{~h}$ after birth), and low total

Table 2. Colostrum IgG concentration (mean, SE in parentheses) descriptive statistics and continuous variables initially evaluated for colostrum IgG univariate screening, by colostrum IgG category $(\mathrm{n}=1,972)$

\begin{tabular}{|c|c|c|c|c|c|c|c|c|c|c|}
\hline Variable & $\begin{array}{l}\text { Mean } \\
(\mathrm{SE})\end{array}$ & \multicolumn{5}{|c|}{ Percentile } & \multicolumn{3}{|c|}{ Colostrum IgG category } & $P$-value \\
\hline $\begin{array}{l}\text { Day length in month } \\
\text { before calving (h:min) }\end{array}$ & $12: 21(0: 03)$ & $8: 58$ & $10: 17$ & $12: 28$ & $14: 28$ & $15: 30$ & $12: 29(0: 09)$ & $12: 12(0: 10)$ & $12: 21(0: 03)$ & 0.872 \\
\hline
\end{tabular}


Table 3. Results of multivariable modeling of factors associated with colostrum IgG fed to Holstein heifer calves $(\mathrm{n}=1,972)$

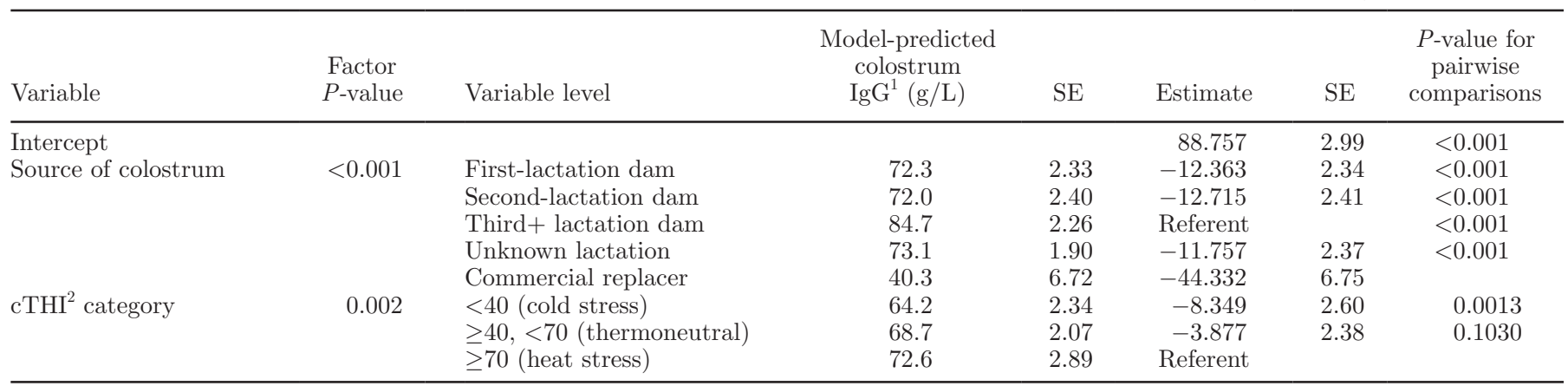

${ }^{1}$ Least squares means, which are the average response for operations with the given characteristic, averaged across all other characteristics in the model.

${ }^{2}$ Temperature-humidity index according to the thermal neutral zone for a mature cow for the month before calving.

volume of colostrum fed in the first $24 \mathrm{~h}(<3.79 \mathrm{~L}$ of colostrum). In this study, the administration of poorquality colostrum (colostrum IgG concentration $\leq 50$ $\mathrm{g} / \mathrm{L}$ ) accounted for $46.2 \%$ of calves with FPT (Table 7 ). Of the 197 calves with FPT, 106 (53.8\%) received excellent colostrum (colostrum IgG concentration $>50 \mathrm{~g} / \mathrm{L}$ ), $36.6 \%$ had delayed feeding of colostrum and $58.8 \%$ were fed a low total volume of colostrum within the first 24 $\mathrm{h}$ after birth. Overall, $14.2 \%$ of calves with FPT $(1.7 \%$ of all calves) had no apparent risk factors for FPT; they received high-quality colostrum within $4 \mathrm{~h}$ after birth and were administered $>3.79 \mathrm{~L}$ of colostrum within the first $24 \mathrm{~h}$. Of the $12.1 \%$ of calves with FTP, only $8.1 \%$ had all the apparent risk factors for FPT.

\section{DISCUSSION}

Colostrum quality is generally defined by $\operatorname{IgG}$ concentration, with concentrations of $\operatorname{IgG}>50 \mathrm{~g} / \mathrm{L}$ indicating excellent quality colostrum (McGuirk and Collins, 2004). Results from this study showed that overall colostrum quality available to heifer calves on US dairy farms was excellent. The mean concentration of 74.4 $\mathrm{g} / \mathrm{L}$ of IgG was significantly higher than the goal of $50 \mathrm{~g} / \mathrm{L}$ and similar to the mean of $68.8 \mathrm{~g} / \mathrm{L}$ previously reported (Morrill et al., 2012). Additionally, more than three-fourths of colostrum samples tested $(77.4 \%)$ were above the target IgG concentration of $50 \mathrm{~g} / \mathrm{L}$. This shows significant improvement in colostrum quality

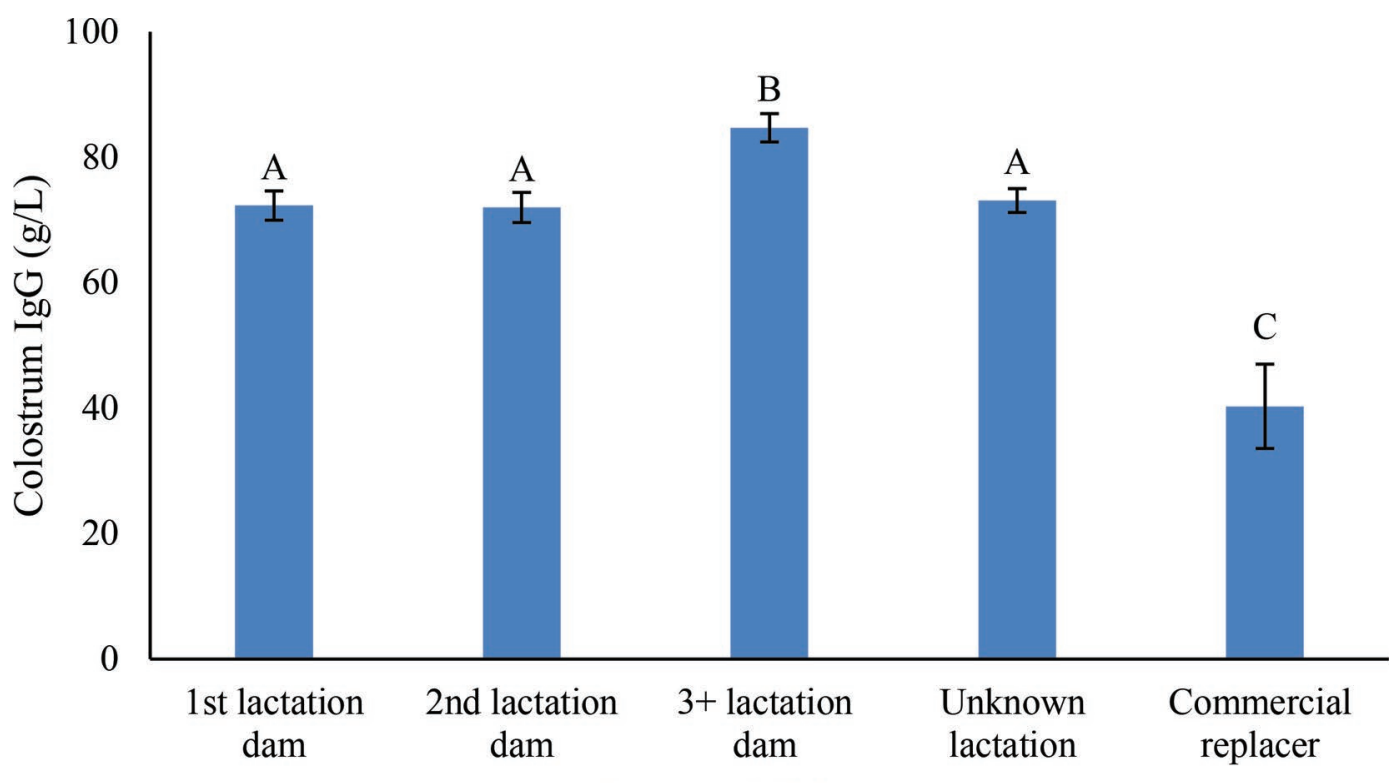

Source of Colostrum

Figure 2. Model-predicted colostrum IgG (g/L) values for different sources of colostrum. Bars with different letters (A-C) are significantly different. Error bars show \pm SE. Color version available online. 
SHIVLEY ET AL.

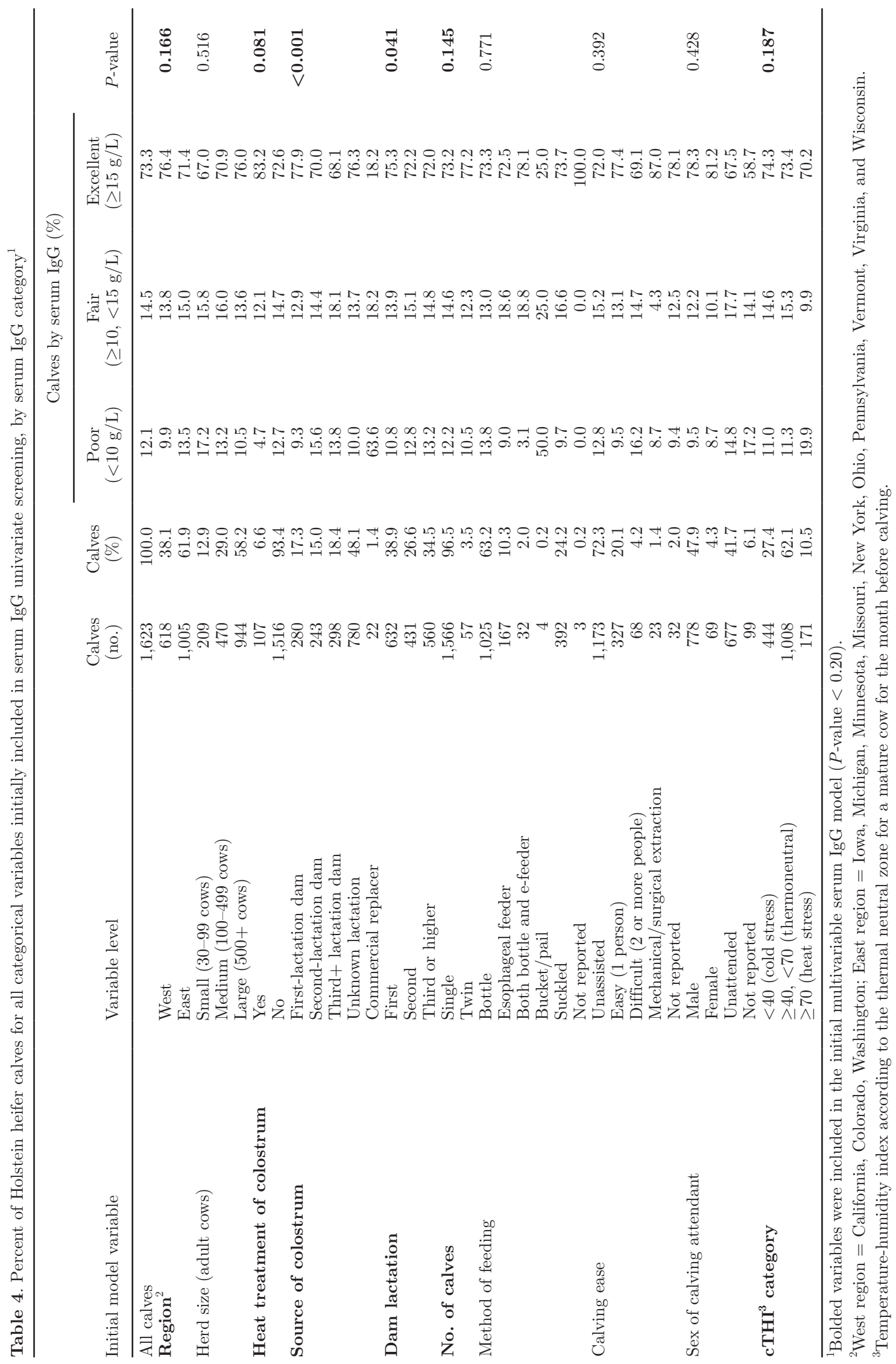


since 1992, when $93.3 \%$ of samples on a Florida dairy had colostrum IgG concentrations $<50 \mathrm{~g} / \mathrm{L}$ (Shearer et al., 1992). However, $22.6 \%$ of colostrum samples in the current study had IgG $<50 \mathrm{~g} / \mathrm{L}$ and $13.2 \%$ had concentrations $<40 \mathrm{~g} / \mathrm{L}$. Considering the ease and availability of on-farm assessment tools for colostrum quality, including colostrometer and Brix refractometers, producers should be encouraged to test and avoid feeding poor-quality colostrum (Quigley et al., 2013).

Factors associated with colostrum quality included the source of colostrum and cTHI for the month before calving. Colostrum IgG concentration was significantly higher when the cTHI was $>70$. Cabral et al. (2016) showed similar results, with a positive correlation between colostrum IgG concentration and number of days above the thermoneutral zone in the 21-d prepartum period. Colostrum creation begins during the dry period in the weeks before calving, so environmental factors that influence colostrum quality would likely have the greatest influence during the month before calving (Godden, 2008). One possible explanation is that as the cTHI rises above the thermoneutral range, vasodilation leads to increased permeability of the blood vessels and possibly an increased amount of IgG passes into the colostrum in the mammary gland (Cabral et al., 2016). The authors of that study were unable to determine whether cTHI or day length was contributing to colostrum quality. In the current study, both factors were included in the initial multivariable model for colostrum IgG concentration but only cTHI was significantly associated with colostrum IgG concentration. Alternatively, cold stress could negatively affect colostrum production. Because cTHI was collected as a monthly average, extremes were not seen at either end. Relatively few calves received colostrum samples $(11.0 \%)$ collected in the heat stress zone for cattle (cTHI $\geq 70$ ), so perhaps the potential negative effect of heat stress on colostrum formation was not detected in this study.

The source of colostrum was also associated with colostrum quality. Colostrum samples from dams in third or greater lactation had the highest quality, as previously reported by Tyler et al. (1999). As cows age, they are exposed to more farm-specific pathogens, potentially increasing the $\mathrm{IgG}$ concentration in the colostrum (Godden, 2008). Discarding colostrum from first-calf heifers was once a common practice (Tyler et al., 1999), yet our results showed no significant difference in colostrum quality between first- and second- lactation dams. Colostrum samples from pooled samples, other dams, or dams without lactation information were categorized as "unknown lactation." The quality of unknown-lactation colostrum was closest to that of first-lactation dams, and between that of first-lactation and third or higher 
Table 6. Results of multivariable modeling of factors significantly associated with serum IgG of Holstein heifer calves $(\mathrm{n}=1,623)$

\begin{tabular}{|c|c|c|c|c|c|c|c|}
\hline Variable & $\begin{array}{l}\text { Factor } \\
P \text {-value }\end{array}$ & Variable level & $\begin{array}{c}\text { Model- } \\
\text { predicted serum } \\
\operatorname{IgG}^{1}(\mathrm{~g} / \mathrm{L})\end{array}$ & $\mathrm{SE}$ & Estimate & $\mathrm{SE}$ & $\begin{array}{c}P \text {-value } \\
\text { for pairwise } \\
\text { comparisons }\end{array}$ \\
\hline Intercept & \multirow{2}{*}{0.041} & & & & 12.125 & 1.54 & $<0.001$ \\
\hline Region $^{2}$ & & East & 21.5 & 0.92 & Referent & & \\
\hline \multirow[t]{2}{*}{ Heat-treated colostrum } & \multirow[t]{2}{*}{0.018} & Yes & 24.4 & 1.72 & 3.904 & \multirow[t]{2}{*}{1.65} & \multirow[t]{2}{*}{0.018} \\
\hline & & No & 20.5 & 0.61 & Referent & & \\
\hline \multirow{3}{*}{ Source of colostrum } & \multirow{3}{*}{$<0.001$} & Third+ lactation dam & 22.4 & 1.09 & 3.350 & 0.77 & $<0.001$ \\
\hline & & Unknown lactation & 23.6 & 0.86 & 1.731 & 0.80 & 0.030 \\
\hline & & Commercial replacer & 16.6 & 2.21 & Referent & & \\
\hline Timing to colostrum feeding (h) & 0.004 & & -0.32 & 0.11 & -0.317 & 0.11 & 0.004 \\
\hline Total volume in $24 \mathrm{~h}(\mathrm{~L})$ & 0.013 & & 0.57 & 0.21 & 0.529 & 0.21 & 0.013 \\
\hline Age at blood sample (d) & $<0.001$ & & -0.71 & 0.16 & -0.714 & 0.16 & $<0.001$ \\
\hline Colostrum IgG (g/L) & $<0.001$ & & 0.11 & 0.01 & 0.106 & 0.01 & $<0.001$ \\
\hline
\end{tabular}

${ }^{1}$ Least squares means, which are the average response for operations with the given characteristic, averaged across all other characteristics in the model.

${ }^{2}$ West region $=$ California, Colorado, Washington; East region = Iowa, Michigan, Minnesota, Missouri, New York, Ohio, Pennsylvania, Vermont, Virginia, and Wisconsin.

lactation dams. This was as expected because these samples likely came from first- and second-lactation dams as they represent the majority of cows on farms.

Calves fed commercial colostrum replacers or supplements had the lowest concentrations of IgG, with a mean of only $39.5 \mathrm{~g} / \mathrm{L}$, but only 23 calves were administered these products. This study did not differentiate between colostrum supplements and colostrum replacers or determine whether they were fed according to label directions. Colostrum supplements tend to have low concentrations of IgG with poor absorption, especially if used as a colostrum substitute, because they are intended to add IgG to poor-quality maternal colostrum (Godden and James, 2014). Colostrum replacers vary widely in IgG concentration, although they should provide a minimum of $100 \mathrm{~g}$ of IgG per dose (Quigley et al., 2001; Godden and James, 2014). Feeding 2 doses of lacteal-derived colostrum replacer for total IgG consumption $>200 \mathrm{~g}$ decreased the risk of FPT compared with feeding raw pooled colostrum, making

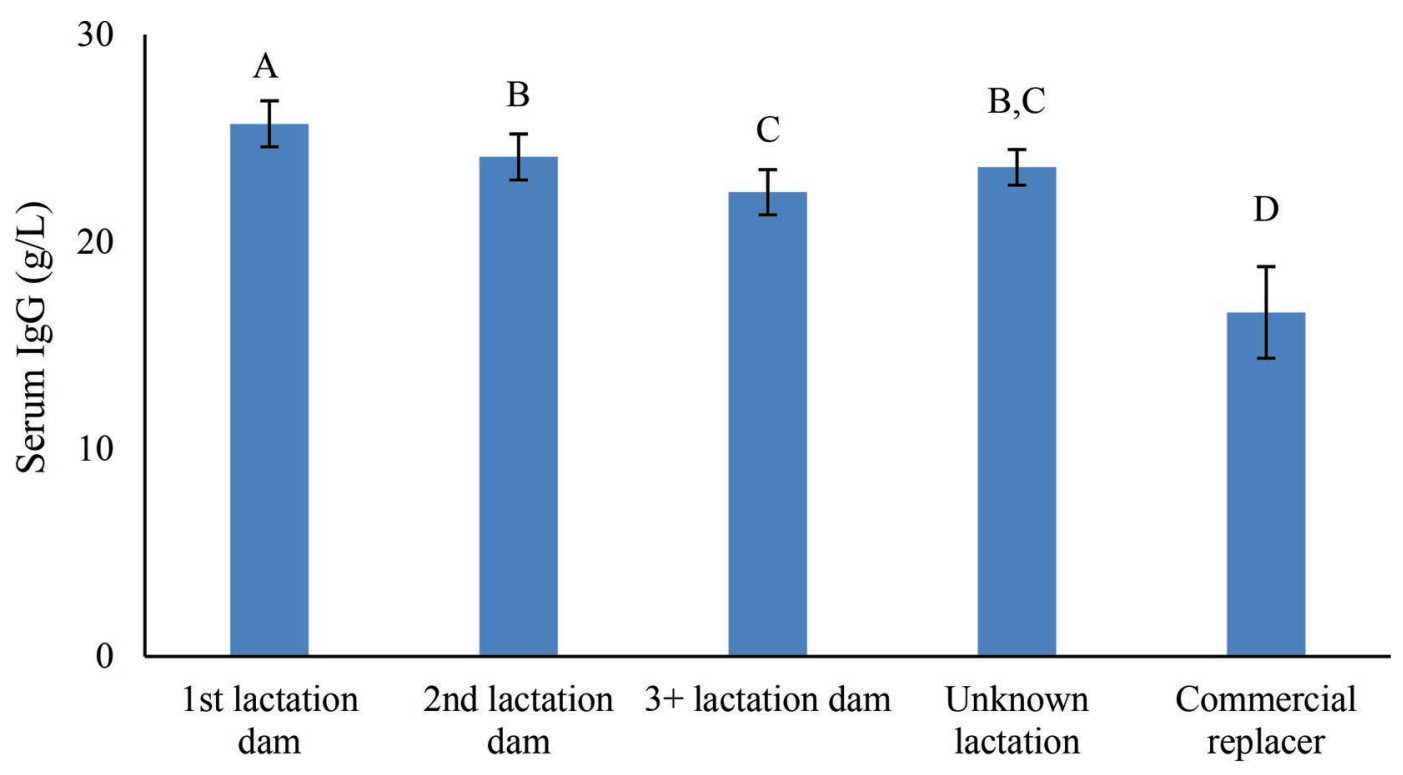

Source of Colostrum

Figure 3. Model-predicted serum IgG (g/L) values for different sources of colostrum. Bars with different letters (A-D) are significantly different. Error bars show \pm SE. Color version available online. 
Table 7. Factors associated with failure of passive transfer (serum $\operatorname{IgG}<10 \mathrm{~g} / \mathrm{L}$ ) in Holstein heifer calves $(\mathrm{n}=197)$

\begin{tabular}{lccc}
\hline $\begin{array}{l}\text { Received high-quality } \\
\text { colostrum }(>50 \mathrm{~g} / \mathrm{L} \mathrm{IgG})\end{array}$ & $\begin{array}{c}\text { Fed first colostrum } \\
\text { in less than } 4 \mathrm{~h}\end{array}$ & $\begin{array}{c}\text { Fed more than 3.79 L } \\
\text { of colostrum within } 24 \mathrm{~h}\end{array}$ & $\begin{array}{c}\text { Percent of calves with FPT } \\
(\text { serum IgG }<10 \mathrm{~g} / \mathrm{L})\end{array}$ \\
\hline Yes & Yes & Yes & 14.2 \\
Yes & Yes & No & 21.8 \\
Yes & No & No & 11.7 \\
Yes & No & Yes & 6.1 \\
No & Yes & No & 4.6 \\
No & Yes & Yes & 22.8 \\
No & No & No & 10.7 \\
No & No & & 8.1 \\
Total & & 100.0 \\
\hline
\end{tabular}

lacteal-derived colostrum replacers a viable alternative for preventing FPT when fed properly (Pithua et al., 2011). Although colostrum replacers can be used when high-quality maternal colostrum is unavailable or when trying to minimize disease transmission to the calf via colostrum, natural colostrum from the farm can have higher $\operatorname{IgG}$ concentrations and protects against farm-specific pathogens. Because of the variation in colostrum quality, all colostrum should be tested on farm to identify high-quality colostrum suitable for feeding. The variability in colostrum quality requires testing all colostrum on farm (using, for example, a Brix refractometer or hydrometer) for indicators of IgG concentration. Producers should feed only high-quality colostrum or feed colostrum products with known mass of $\operatorname{IgG}$ that is $>50 \mathrm{~g} / \mathrm{L}$ when reconstituted.

Passive transfer of immunity can be estimated using total protein or a Brix refractometer; however, measuring serum IgG concentration gives the most accurate indication of passive transfer status (Deelen et al., 2014). Calves with serum IgG concentrations $<10 \mathrm{~g} / \mathrm{L}$ are considered to have FPT, and those with serum IgG concentrations $>15 \mathrm{~g} / \mathrm{L}$ are considered to have excellent passive transfer of immunity. Overall, calves in this study had excellent passive transfer with an average serum IgG of $21.6 \mathrm{~g} / \mathrm{L}$, and $73.3 \%$ of calves had excellent passive transfer.

Factors associated with serum IgG included region, heat treatment of colostrum, source of colostrum, timing to the first feeding, total volume of colostrum fed in the first $24 \mathrm{~h}$ of life, age of the calf at blood sample, and colostrum IgG. The age of the calf at blood sample was included in the model as a covariate due to the known decrease of serum immunoglobulins during the first month of life (Tóthová et al., 2015). The calf's age at the time of blood collection was significantly related to serum IgG in the final model, with serum IgG decreasing as days of age at sampling increased.

Source of colostrum had a different effect on serum IgG than on colostrum IgG. The highest serum IgG concentrations were in calves fed colostrum from first- lactation dams, followed by second-lactation dams, unknown dams, third or higher lactation dams, and lowest for commercial colostrum replacer. Dam lactation and birth weight were correlated: mean calf birth weight increased with increasing parity. During a preliminary analysis using a subset of the final data set, birth weight was negatively associated with serum IgG concentration. Perhaps this explains why calves from first-lactation dams had the highest concentrations of serum IgG despite the opposite effect of lactation on colostrum quality. Because the commercial colostrum replacers fed had the lowest colostrum IgG concentration, it is not surprising that calves that received it as their source of colostrum had the lowest serum IgG concentrations. Additionally, absorption of $\operatorname{IgG}$ from serum-derived colostrum replacers has been shown to be lower than absorption of natural colostrum (Garry et al., 1996; Quigley et al., 2002; Swan et al., 2007). The source of IgG in colostrum replacers also influences absorption, with colostrum-derived replacers generally being better absorbed than serum-derived replacers (Godden and James, 2014). This study did not elucidate the type of colostrum replacer used, and overall passive transfer of immunity in calves fed colostrum replacers was excellent.

A calf's enterocytes have the ability to nonselectively absorb large molecules, including IgG, by pinocytosis. These molecules are transported across the cell and deposited into the lymphatic system via exocytosis (Godden, 2008). From there, the molecules are absorbed into the bloodstream through the thoracic duct. This process decreases linearly from the time of birth until gut closure is complete at approximately $24 \mathrm{~h}$ of age. Because of this, the timing of colostrum feeding is the most important factor for efficient absorption of IgG. The results of the current study found that serum IgG decreased by $0.32 \mathrm{~g} / \mathrm{L}$ for every hour following birth that colostrum was administered. Most experts recommend feeding colostrum as soon as possible after birth, and always within the first $4 \mathrm{~h}$ of life (Michanek et al., 1989; BAMN, 2001). 
An adequate volume and quality of colostrum is essential for adequate passive transfer of immunity. The general recommendation is to feed at least $10 \%$ of $\mathrm{BW}$ of colostrum at the first feeding - about $4 \mathrm{~L}$ for the average size calf (Godden, 2008). This study found that within the range of volume of colostrum administered seen in this study, for every $1 \mathrm{~L}$ of colostrum administered during the first $24 \mathrm{~h}$ of life, serum IgG increased by $0.57 \mathrm{~g} / \mathrm{L}$, indicating that more colostrum leads to higher passive transfer. Increased serum IgG is related to the total mass of $\operatorname{IgG}$ administered to the calf, which can occur by feeding a larger volume of colostrum or a high IgG concentration of colostrum, or both. The final model for serum IgG included both volume of colostrum fed and colostrum IgG concentration. For every $10 \mathrm{~g} / \mathrm{L}$ increase in colostrum IgG concentration, serum $\mathrm{IgG}$ increased by $1.1 \mathrm{~g} / \mathrm{L}$, indicating that higher quality colostrum resulted in better passive transfer.

Calves that received heat-treated colostrum had higher serum $\operatorname{IgG}$ concentrations than calves that did not receive heat-treated colostrum. Heat treatment of colostrum needs to be performed at a lower temperature $\left(60^{\circ} \mathrm{C}\right)$ for a longer period $(60 \mathrm{~min})$ compared with milk pasteurization to avoid IgG denaturation. Heat treatment is a tool to reduce bacterial contamination of colostrum (Godden, 2008; Armengol and Fraile, 2016). Johnson et al. (2007) showed similar results, with heattreated colostrum having lower bacterial loads and better IgG absorption. Decreasing the bacterial load in colostrum improves absorption of IgG, although the exact mechanism is not well understood. One theory is that colostrum IgG in the intestinal lumen has fewer bacteria to bind to, resulting in more IgG to be absorbed. A second theory is that colostrum IgG has fewer bacteria to compete with during pinocytosis, resulting in increased absorption (Godden, 2008). Only a small percentage of calves were fed heat-treated colostrum (6.6\%) compared with raw colostrum or colostrum replacer, so this is a potential area for improvement for colostrum management on farm.

Interestingly, region was associated with serum $\operatorname{IgG}$, with calves in the west region having higher $\mathrm{IgG}$ concentrations than calves in the east region. Although we tried to account for many management factors, other factors might exist that were not accounted for, resulting in the regional association. There was a strong association of cTHI with region, with the east region having a lower average and a narrower range of cTHI than the west region. Perhaps cold stress in calves interferes with colostrum absorption, as suggested by Olson et al. (1981). Thermal heat stress can also negatively affect absorption of colostrum IgG (Stott et al., 1976).

Overall, $12.1 \%$ of calves had FPT, increasing their risk for morbidity and mortality (Weaver et al., 2000).
This study supports the trend of decreasing prevalence of FPT in dairy heifer calves in the United States. In the 1991-1992 National Dairy Heifer Evaluation Project, more than $40 \%$ of calves had FPT (USDA, 1993). In the USDA NAHMS Dairy 2007 study, 19.2\% of calves had FPT (Beam et al., 2009). The risk factors evaluated for FPT included poor-quality colostrum ( $\leq 50 \mathrm{~g} / \mathrm{L}$ colostrum $\operatorname{IgG})$, delayed first feeding of colostrum ( $\geq 4 \mathrm{~h}$ after birth), and inadequate total volume of colostrum fed in the first $24 \mathrm{~h}(\leq 3.79 \mathrm{~L})$. Among calves with FPT, $85.8 \%$ had one or more of the risk factors associated with FPT. All of the risk factors associated with FPT were present for $8.1 \%$ of calves with FPT. Among the calves with FPT, $46.2 \%$ received poor-quality colostrum, resulting in FPT.

Of all calves with FPT, $14.2 \%$ had FPT without any of the described risk factors. Colostrum quality was measured in a laboratory but timing and volume fed were self-reported numbers, and some of the calves with FPT might not have received colostrum at the time indicated or the total amount reported. Some operations appeared to report based on standard operating procedures, and there may have been variation at the individual calf level, resulting in FPT. Additionally, other factors associated with absorption of IgG could account for these calves with FPT and no apparent associated risk factors, such as biological variation in gut absorptive function or gut exposure to bacteria before colostrum administration. Bacterial contamination of colostrum was not assessed and could result in decreased absorptive capacity of immunoglobulins (Johnson et al., 2007). In the planning phases of the study, quantifying bacterial concentration in colostrum samples was considered, but due to challenges in consistent sample collection, storage, and shipping, this was not performed.

Because this was a nationwide field study, there were some limitations in study design. A greater number of producers were expected to participate in the study than actually did, making this study a convenience sample rather than representative of dairy heifer management across the US dairy industry. However, the number of calves was large and operations from 13 states participated. There was a large variation among operations in the quality of the information provided. Data collected on-farm included self-reporting on the Calf Card, with some operations reporting standard operating procedures rather than individual calf-level practices.

Colostrum quality (colostrum IgG) was most significantly affected by source of colostrum and the categorized cTHI for the month before birth. Colostrum from third-lactation dams had the highest IgG concentrations, and commercial colostrum replacers had the low- 
est IgG concentrations. Colostrum IgG was positively correlated with cTHI.

Passive transfer (serum IgG) was also affected by the source of colostrum, though in a different pattern than colostrum quality - calves receiving colostrum from first-lactation dams had the highest serum IgG concentrations and calves receiving commercial colostrum replacers had the lowest. Calves that received heattreated colostrum had higher serum IgG than calves that received untreated colostrum. Geographic region also affected serum IgG. Serum IgG increased as time to the first feeding decreased, total volume of colostrum fed in the first $24 \mathrm{~h}$ increased, age of the calves at blood sample decreased, and quality of the colostrum increased (colostrum IgG). These results indicate that prompt feeding of high-quality colostrum in appropriate amounts following birth, as well as environmental factors, is important to the passive transfer status of dairy heifer calves.

Dairy producers should be encouraged to measure colostrum quality before administering colostrum to calves and to measure serum IgG or a proxy measure such as serum total protein or Brix to evaluate passive immunity and colostrum management programs.

\section{ACKNOWLEDGMENTS}

Data are from a dissertation submitted to Colorado State University by C. B. Shivley in partial fulfilment of requirements for the $\mathrm{PhD}$ degree. Portions of this manuscript were presented at the 2015 and 2016 ADSA and ASAS Joint Annual Meetings. We thank the 104 dairy producers and their staff for participating in the study; the Federal and State Animal Health personnel who assisted in collecting the data; Judy Rodriguez (USDA NAHMS, Fort Collins, CO) for technical assistance in data validation and analysis; Ashley Adams (Agricultural Science, Business, and Dairy Department, Morrisville State College, Morrisville, NY), Ken Leslie (Ontario Veterinary College, University of Guelph, Guelph, ON, Canada), Jud Heinrichs (Department of Animal Science, Pennsylvania State University, University Park), Robert James (Down Home Heifer Solutions Inc., Blacksburg, VA), Dan Catherman (Strauss Feeds, Watertown, WI), Nina von Keyserlingk (Animal Welfare Program, Faculty of Land and Food Systems, University of British Columbia, Vancouver, BC, Canada), and Daniel Weary (Animal Welfare Program, Faculty of Land and Food Systems, University of British Columbia, Vancouver, BC, Canada) for their guidance in study design and analysis; and Temple Grandin (Department of Animal Sciences, College of Agricultural Sciences, Colorado State University, Fort
Collins) for assisting in funding Dr. Shivley during her $\mathrm{PhD}$ program.

\section{REFERENCES}

Armengol, R., and L. Fraile. 2016. Colostrum and milk pasteurization improve health status and decrease mortality in neonatal calves receiving appropriate colostrum ingestion. J. Dairy Sci.https://doi .org/ 99:4718-4725. 10.3168/jds.2015-10728.

BAMN. 2001. A guide to colostrum and colostrum management for dairy calves. Bovine Alliance on Management and Nutrition (BAMN). Accessed Mar. 29, 2016. https://www.aphis.usda .gov/animal_health/nahms/dairy/downloads/bamn/BAMN01 _Colostrum.pdf.

Beam, A. L., J. E. Lombard, C. A. Kopral, L. P. Garber, A. L. Winter, J. A. Hicks, and J. L. Schlater. 2009. Prevalence of failure of passive transfer of immunity in newborn heifer calves and associated management practices on US dairy operations. J. Dairy Sci. 92:3973-3980.

Cabral, R. G., C. E. Chapman, K. M. Aragona, E. Clark, M. Lunak, and P. S. Erickson. 2016. Predicting colostrum quality from performance in the previous lactation and environmental changes. J. Dairy Sci. 99:4048-4055.

Chigerwe, M., J. V. Hagey, and S. S. Aly. 2015. Determination of neonatal serum immunoglobulin $\mathrm{G}$ concentrations associated with mortality during the first 4 months of life in dairy heifer calves. J. Dairy Res. 82:400-406.

Deelen, S. M., T. L. Ollivett, D. M. Haines, and K. E. Leslie. 2014. Evaluation of a Brix refractometer to estimate serum immunoglobulin $\mathrm{G}$ concentration in neonatal dairy calves. J. Dairy Sci. $97: 3838-3844$

DeNise, S. K., J. D. Robison, G. H. Stott, and D. V. Armstrong. 1989. Effects of passive immunity on subsequent production in dairy heifers. J. Dairy Sci. 72:552-554.

Faber, S. N., N. E. Faber, T. C. Mccauley, and R. L. Ax. 2005. Case study: Effects of colostrum ingestion on lactational performance. Prof. Anim. Sci. 21:420-425.

Famulener, L. 1912. On the transmission of immunity from mother to offspring: A study upon serum hemolysins in goats (with discussion). J. Infect. Dis. 10:332-368.

Furman-Fratczak, K., A. Rzasa, and T. Stefaniak. 2011. The influence of colostral immunoglobulin concentration in heifer calves' serum on their health and growth. J. Dairy Sci. 94:5536-5543.

Garry, F. B., R. Adams, M. B. Cattell, and R. P. Dinsmore. 1996. Comparison of passive immunoglobulin transfer to dairy calves fed colostrum or commercially available colostral-supplement products. J. Am. Vet. Med. Assoc. 208:107-110.

Gay, C. C. 1983. Failure of passive transfer of colostral immunoglobulins and neonatal disease in calves: A review. Pages 346-362 in Proc. 4th Int. Symp. Neonatal Dis. Veterinary Infectious Disease Organization, Saskatoon, SK, Canada.

Godden, S. 2008. Colostrum management for dairy calves. Vet. Clin. North Am. Food Anim. Pract. 24:19-39.

Godden, S. M., and R. E. James. 2014. Colostrum and Milk Replacers. Pages 339-348 in Large Animal Internal Medicine. 5th ed. B. P. Smith, ed. Elsevier Health Sciences, Philadelphia, PA.

Gulliksen, S. M., K. I. Lie, L. Sølverød, and O. Østerås. 2008. Risk factors associated with colostrum quality in Norwegian dairy cows. J. Dairy Sci. 91:704-712.

Johnson, J. L., S. M. Godden, T. Molitor, T. Ames, and D. Hagman. 2007. Effects of feeding heat-treated colostrum on passive transfer of immune and nutritional parameters in neonatal dairy calves. J. Dairy Sci. 90:5189-5198.

Larson, B. L., H. L. Heary, and J. E. Devery. 1980. Immunoglobulin production and transport by the mammary gland. J. Dairy Sci. 63:665-671.

McGuirk, S. M., and M. Collins. 2004. Managing the production, storage, and delivery of colostrum. Vet. Clin. North Am. Food Anim. Pract. 20:593-603. 
Michanek, P., M. Ventorp, and B. Weström. 1989. Intestinal transmission of macromolecules in newborn dairy calves of different ages at first feeding. Res. Vet. Sci. 46:375-379.

Morrill, K. M., E. Conrad, A. Lago, J. Campbell, J. Quigley, and H. Tyler. 2012. Nationwide evaluation of quality and composition of colostrum on dairy farms in the United States. J. Dairy Sci. 95:3997-4005.

NOAA. 2016. Quality controlled local climatological data (QCLCD) Accessed Mar. 1, 2016. https://www.ncdc.noaa.gov/data-access/ land-based-station-data/land-based-datasets/quality-controlled -local-climatological-data-qclcd.

Nocek, J. E., D. G. Braund, and R. G. Warner. 1984. Influence of neonatal colostrum administration, immunoglobulin, and continued feeding of colostrum on calf gain, health, and serum protein. J. Dairy Sci. 67:319-333.

Olson, D. P., R. C. Bull, L. F. Woodard, and K. W. Kelley. 1981. Effects of maternal nutritional restriction and cold stress on young calves: absorption of colostral immunoglobulins. Am. J. Vet. Res. 42:876-880.

Ontsouka, C. E., R. M. Bruckmaier, and J. W. Blum. 2003. Fractionized milk composition during removal of colostrum and mature milk. J. Dairy Sci. 86:2005-2011.

Pithua, P., S. S. Aly, J. Champagne, S. Hendrick, J. R. Middleton, and S. E. Poock. 2011. Passive transfer of immunity, preweaning health, and growth in Holstein calves fed a bovine lacteal-derived colostrum replacer or raw pooled colostrum. Page 173 in Proceedings of the AABP Annual Conference, St. Louis, MO. American Association of Bovine Practitioners, Ashland, $\mathrm{OH}$.

Quigley, J. D., C. J. Kost, and T. M. Wolfe. 2002. Absorption of protein and $\operatorname{IgG}$ in calves fed a colostrum supplement or replacer. J. Dairy Sci. 85:1243-1248.

Quigley, J. D., A. Lago, C. Chapman, P. Erickson, and J. Polo. 2013 Evaluation of the Brix refractometer to estimate immunoglobulin G concentration in bovine colostrum. J. Dairy Sci. 96:1148-1155.

Quigley, J. D., R. E. Strohbehn, C. J. Kost, and M. M. O'Brien. 2001. Formulation of colostrum supplements, colostrum replacers and acquisition of passive immunity in neonatal calves. J. Dairy Sci. 84:2059-2065.

Robison, J. D., G. H. Stott, and S. K. DeNise. 1988. Effects of passive immunity on growth and survival in the dairy heifer. J. Dairy Sci. 71:1283-1287.

Shearer, J., H. O. Mohammed, J. S. Brenneman, and T. Q. Tran. 1992. Factors associated with concentrations of immunoglobulins in colostrum at the first milking post-calving. Prev. Vet. Med. 14:143-154.

Stewart, S., S. Godden, R. Bey, P. Rapnicki, J. Fetrow, R. Farnsworth, M. Scanlon, Y. Arnold, L. Clow, K. Mueller, and C. Ferrouillet.
2005. Preventing bacterial contamination and proliferation during the harvest, storage, and feeding of fresh bovine colostrum. J. Dairy Sci. 88:2571-2578.

Stott, G. H., D. B. Marx, B. E. Menefee, and G. T. Nightengale 1979. Colostral immunoglobulin transfer in calves: II. The rate of absorption. J. Dairy Sci. 62:1766-1773.

Stott, G. H., F. Wiersma, B. E. Menefee, and F. R. Radwanski. 1976 Influence of environment on passive immunity in calves. J. Dairy Sci. 59:1306-1311.

Swan, H., S. Godden, R. Bey, S. Wells, J. Fetrow, and H. ChesterJones. 2007. Passive transfer of immunoglobulin $\mathrm{G}$ and preweaning health in Holstein calves fed a commercial colostrum replacer. J. Dairy Sci. 90:3857-3866.

Tóthová, C., O. Nagy, G. Kováč, and V. Nagyová. 2015. Changes in the concentrations of serum proteins in calves during the first month of life. J. Appl. Anim. Res. 44:338-346.

Tyler, J. W., B. J. Steevens, D. E. Hostetler, J. M. Holle, and J. L. Denbigh. 1999. Colostral immunoglobulin concentrations in Hol stein and Guernsey cows. Am. J. Vet. Res. 60:1136-1139.

Urie, N. J., J. E. Lombard, C. B. Shivley, C. A. Kopral, A. E. Adams, T. J. Earleywine, J. D. Olson, and F. B. Gary. 2018. Preweaned heifer management on US dairy operations: Part I. Descriptive characteristics of preweaned heifer raising practices. J. Dairy Sci. 101:9168-9184. https://doi.org/10.3168/jds.2017-14010.

USDA. 1993. Transfer of maternal immunity to calves. USDA-APHISVS-CEAH, Fort Collins, CO. Accessed Apr. 1, 2016. https:// webcache.googleusercontent.com/search?q=cache:h0OYNF _2ixMJ:https://www.aphis.usda.gov/animal_health/nahms/ dairy/downloads/ndhep/NDHEP_Immunity.pdf $+\& c d=1 \& h l=e n$ $\& c t=\operatorname{lnk} \& g l=$ us\&client $=$ safari.

USDA. 2016. National Animal Health Monitoring System (NAHMS) Accessed Mar. 29, 2016. https://www.aphis.usda.gov/animal _health/nahms.

USNO (US Naval Observatory). 2016. Duration of daylight/darkness table for one year. Accessed Mar. 1, 2016. http://aa.usno.navy .mil/data/docs/Dur_OneYear.php.

Weaver, D. M., J. W. Tyler, D. C. VanMetre, D. E. Hostetler, and G. M. Barrington. 2000. Passive transfer of colostral immunoglobulins in calves. J. Vet. Intern. Med. 14:569-577.

Wells, S. J., D. A. Dargatz, and S. L. Ott. 1996. Factors associated with mortality to 21 days of life in dairy heifers in the United States. Prev. Vet. Med. 29:9-19.

Zarcula, S., H. Cernescu, C. Mircu, C. Tulcan, A. Morvay, S. Baul, and D. Popovici. 2010. Influence of breed, parity and food intake on chemical composition of first colostrum in cow. Lucr. Stiint. Zooteh. Biotehnol. 43:154-157. 